\title{
ANATOMICAL AND SURFACE MORPHOLOGY OF HEDRURIS LUT- JANENSES SP. N. (NEMATODA: HEDRURIDAE) FROM THE COMMON MARINEWATER FISH LUTJANUS SYNAGRIS IN DAMIETTA, EGYPT
}

\author{
By \\ M. M. RAMADAN, E. R. AWAD AND R. G.TAHA \\ Department of Biology, Faculty of Education, Ain Shams University, Cairo, Egypt
}

\begin{abstract}
The description and tegumental ultrastructure of nematode Hedruris lutjanenses sp. n. collected from marine Lane Snapper fish Lutjanus synagris Linnaeus, 1758 collected at Manzala Lake, Damietta, Egypt was studied by light and Scanning Electron Microscopy (SEM). The new species is mainly characterized by that the buccal capsule is surrounded by four pseudolapia; one small and three larger pseudolapia, each one bears a number of papillae arranged irregularly on its surface and the presence of one pair of precloacal papillae and nine pairs of postcloacal ones in males.
\end{abstract}

Key words: Egypt, Damietta, Hedruris Lutjanenses, Sp. N. Lutjanus synagris

\section{Introduction}

Manzala Lake is the largest of the northern deltaic lakes of Egypt and serves as a significant source of inexpensive fish for human consumption. Its mean annual fish production is 60 thousand ton (Dinar, 1995; Zahran, 2008). Family Hedruridae contains a single genus Hedruris and their species have a worldwide distribution. Many species of the present genus are described by many authors such as Petter (1971) who studied $H$. androphora and discussed the taxonomic affinities of the Hedruridae. Andrews (1974) described $H$. minuta as new species from the stomach of the skink Leiolopisma smithi from New Zealand. The new species is characterized by its small body size and the presence of 11 pairs of caudal papillae; one pair lies preanal and the remainder is post-anal. Griffiths (1976) studied the role of feeding type on the degree of infection by $H$. spinigera in Perch Perca fluviatilis collected from Selwyn River, New Zealand. Clark (1978) examined the surface topography of the heads of $H$. spinigera from Galaxias maculates, Retropinna retropinna and Anguilla australis from lake Ellesmere, New Zealand by Scanning Electron Microscope. He showed subsurface structures that included papillae and amphids situated in the longitudinal midline of the pseudolabia. Baker (1986) recognized five species of Hedruris nematode from aquatic vertebrates in North America; H. pendula (Leidy, 1851) Chandler, 1919, H. siredonis Baird, 1858; $H$. tiara Van Cleave and Mueller, 1932; H. chandleri Freitas and Lent, 1941 and H. brevis Walton, 1930.

Bursey and Goldberg (2000) described $H$. hanleyae as new species from stomach of lizard Hemidactylus garnotii from Cook Islands, Oceania. It is distinguished by four large chitinized lips, two lateral and two median lips, each one bears two pairs of papillae and amphids and the distribution pattern of caudal papillae of male; ten pairs lie posterior subventral; two pairs precloacal and eight pairs are postcloacal. They (2007) described the new species $H$. heyeri from stomach of amphibian Lithobates warszewitshii from Costa Rica. It is distinguished by the distribution pattern of caudal papillae of male; thus two pairs are precloacal, one pair is adcloacal and six pairs are postcloacal. Brugni and Viozzi (2010) considered $H$. suttonae as new species from stomach of marine fishes Galaxias maculates and G. platei from Patagonian Andean 
lakes. They stated that the new species is distinct by the cephalic end which has two large lareral psuedolabia, each bearing one pair of small apical papillae, one amphid and a pair of lateral sessile papillae and it is distinguished also by the large size of spicules.

\section{Materials and Methods}

The hosts are collected from Manzala Lake, Damietta, Egypt; during from January to December 2013. Fishes were identified (Burgeese et al, 2002; Schultz, 2003) their sex, length and weight are determined. For light microscope examination, the collected nematodes transferred into a petri dish with physiological saline solution $(0.7 \%)$ for 1 to 2 hrs for relaxation. The specimens were fixed by $7 \%$ Formalin for $12 \mathrm{hrs}$. The fixative was gradually replaced by lactophenol solution by adding 2-3 drops each hour. The specimens were cleaned in few drops of lactophenol. Again, mounting was done by using of lactophenol solution. The borders of the coverslip were sealed by drops of DPX (Abdou, 2007). Drawings are made to scale using the Camera Lucida. All measurements are in millimeters unless stated otherwise. For Scanning Electron Microscopy, the identified worms washed in saline solution $(0.7 \%)$, fixed in $2 \%$ glutraldehyde in $0.1 \mathrm{M}$ sodium cacodylate buffer ( $\mathrm{pH}$ 7.2), washed three times in the same buffer, post fixed in osmium tetroxide (OsO4) for 2 hours, washed again in buffer, dehydrated in ethanol, and CO2 critical point dried (Morsy et al, 2011; Gorgani et al, 2013). The specimens mounted on stubs then coated with gold, examined and photographed at varying magnifications by Joel SEM at the Electron Microscopic Lab of the Atomic Energy Agency, Nasr City, Cairo, Egypt.

\section{Results}

In the present study, Hedruris lutjanenses sp. n. was recorded from marine fish Lutjanus synagris Linnaeus, 1758 collected from Manzala Lake, Damietta, Egypt.
Light Microscopy (Plate 1, Figs. A-H): The following description is based on the examination of sixty nematode specimens and the measurements of eight males and eight female worms.

Anterior end is narrow and rounded, the cephalic capsule has small mouth opening provided with four small cephalic papillae and two lateral amphids. Buccal capsule without spiral bands and surrounded by four pseudolapia; one small submedian pseudolapium and three larger pseudolapia each one bears a number of papillae. Oesophagus is consisting of a long narrow tube. Two bacillary bands are distinct, and a pair of ring like cells present near the junction of oesophagus and intestine.

Male: Body length is $1.9-2.5 \mathrm{~cm}$, maximum width is $0.45-0.68 \mathrm{~cm}$. tapering towards its posterior end.Oesophagus length varies from 0.48-0.55. Buccal capsule measures 0.08-0.09 long by $0.065-0.069$ width. Nerve ring 0.056 lies apart from cephalic end and measures 0.002-0.003 wide. Execretory pore from anterior extremity is 0.19-0.21. Spicules fused, long and slightly curved; each one measures 195-240 $\mu \mathrm{m}$. Spicular sheath well developed measures 0.19-0.2. Caudal papillae are ten in number; a pair is pre-cloacal and remainder is postcloacal.

Female: Body measures $2.6-3 \mathrm{~cm}$. long and its maximum width $0.42-0.6 \mathrm{~cm}$.

Buccal capsule measures 0.1-0.12 long by 0.12-0.14 width. Oesophagus measures 0.50.6 long. Nerve ring is 0.068 from cephalic end and measures 0.002-0.003 wide. Execretory pore lays $0.22-0.23$ from anterior extremity. Tail is rounded or tapering at its posterior end and measures 0.045-0.05. Ovary measures 0.2-0.21 long, vulva measures 0.390.41 and opening into long muscular vagina. Eggs in mature females are cylindrical containing fully developed larvae. Larva measures 0.12-0.14. Eggs measure 75-90 $\mu \mathrm{m}$ in length and $30-33 \mu \mathrm{m}$ in width. Rectum is 
wide elongated tube with no rectal glands and opens by anal opening near the end of the tail. Anus lays $0.14-0.15$ from tail termination. One short curved hook is present invaginated at the end top of female body and measures 0.066-0.08.

SEM (Plate 2, Figs. A-J): SEM of the present nematode showed that the body is cylindrical and transversally striated. The cephalic end is provided by three large pseudolabia and one smaller pseudolabium. The internal edges of large pseudolabia are provided with teeth-like projections and a number of irregularly distributed papillae on their outer surfaces. No interlabia are observed. Two amphids are present one on each side of the cephalic end. Buccal cavity thin walled and mouth opening triangular shaped. Dorso-lateral cuticular ridges extend from the base of each pseudolabium towards the posterior end of nematode body. Cuticle surrounding the cephalic capsule and that of the first third of body is transversally corrugated striated. It is divided at various distances by short longitudinal striations. In female, the vulva exhibited as large invaginated pore located at the end of the ventral surface of first third of nematode body and surrounded by transverse cuticular annulations. The posterior extremity is triangular in shape and has many cuticular ridges; these ridges bear numerous minute spines on their surfaces. A small pointed peg-like sclerotized hook arises from the distal end of female body. The magnification of the anal region showed an invagination in the cuticle and the presence of irregular ribbed-like structures.

In male, two long, cylinder and equal, fused spicules arise from the tail region. Cloacal region has small cloacal papillae and many protruded cuticular structures.

In the present study, (Tab. 2) the nematode $H$. lutjanenses was isolated from the intestine and stomach of Lutjanus synagris. Forty four fishes out of 120 examined fish were infected with total infection rate $(36.66 \%)$. Twenty out of 44 were infected; in males with $45.45 \%$ while, 24 out of $76(31.57 \%)$ were infected in females. The infection with $H$. lutjanenses sp. $\mathrm{n}$. was recorded in relation to the host weight. The infection was found in both large and small sizes of males and females which are ranged from 20-162gms and their length ranged from 17.5-24.5 cm. Among different seasons, the prevalence of infection was higher in winter $(53.57 \%)$ followed by summer $(37.5 \%)$ then spring $(31.82 \%)$ and the lowest infection rate were recorded in autumn season (26.3\%).

\section{Discussion}

The present genus was first proposed by Nitzsch (1821) to include Hedruris androphora from intestine of amphibian Triturus cristatus (Laurenti, 1768). It is the only genus of family Hedruridae which consists of parasites of the digestive tracts of fishes, frogs, salamanders, lizards and turtles (Luque et al, 2010). Members of the present family are characterized by four highly specialized lips and the posterior end of female is invaginated forming a sucker like groove from which projects a chitinous hook (Yamaguti, 1963; Hasegawa 1989; Bursey and Goldberg 2000, 2007). The adult female worms use the terminal caudal hook to attach themselves to the host's stomach wall (Jellyman, 1989). Luque et al. (2010) observed that $H$. spinigera more specifically attached in the epithelium of intestine and rectum of fish that make it rapidly passed out consequently, it has low prevalence, abundance and mean intensity. Untill now the life cycles of only three species of Hedruris have been investigated; $H$. androphora Nitzsch, 1821, H. ijimai Morishita, 1926 and H. suttonae Brugni and Viozzi, 2010 (Hasegawa and Otsuru, 1979; Brugni and Viozzi, 2010).

The morphological characteristics of immature worms of Hedruris sp. are exactly identi- 
cal with those of adults from fishes except by their smaller sizes and absence of eggs (Brugni and Viozzi, 2010). As regards to the distribution of the infection by the present nematode there are 20 identified species of Hedruris nematode distributed worldwide that infect digestive tracts of fishes, frogs, salamanders, lizards and turtles. Of these four are found in the Australian realm, one in the Ethiopian, two in the nearctic, six in the Neotropical and seven in the Palearctic (Bursey and Goldberg, 2000, 2007). Four species of Hedruris have previously been recorded from reptiles; H. longispicula Thomas, 1959, described from the Australian skink Lygosoma challenged, H. armata Perrier, 1871, H. pendula (Leiby, 1851) both recorded from North American freshwater turtles and H. hipsirhinae Chatin, 1876 from a snake in Cochin China (Andrews, 1974). The present species differs from those described species in their much greater sizes. Also, Hedruris lutjanenses sp. $\mathrm{n}$. differs from $H$. sattonae Brugni and Viozzi, 2010, H. androphora Nitzsch, 1821, H. orestiae Moniez, 1889, $H$. ijimai Morishita, 1926, H. basilichtensis Mateo, 1971 and H. Moniezi Ibanez and Cordova, 1976 in that, all previous species have nine pairs of caudal papillae in males while the present described species has ten pairs.

In the present investigation, the high infestation rate by Hedruris nematode was found in large and small sizes of examined fish and it is may be explained by the same diet that they feed and the same environmental factors. Jellyman, (1989) explained the increasing in the abundance of $H$. spinigera with increasing of size in eels Anguilla australis and A. dieffenbachia from lake Pounui Wairarapa by the presence of amphipod host Paracalliope fluviatilis in their diet. Moravec (2007) arrested that amphibians are the true host for the Hedruris sp. so fishes should not be considered true definitive hosts but only accidental facultative post-cyclic hosts (Brugni and Vi- ozzi, 2010). Hedruruis lutjanenses sp. n. in the present study agrees with $H$. spinigera Baylis, 1931, H. bryttosi Yamaguti, 1935, H. miyakoensis Hasegawa, 1989 and H. hanleyae Bursey and Goldberg, 2000 in the number of caudal papillae in male specimens (10) while it differs from them in the arrangement of these papillae around cloacal opening . Hedruruis miyakoensis and $H$. hanleyae have two pairs of precloacal papillae and 8 postcloacal papillae. While in H. bryttosi, no precloacal papillae are found while, in the present study males have one pair of precloacal papillae and nine pairs of postcloacal ones. In the same time, the present specimen differs from $H$. hanleyae in that two pairs of papillae are found on each lateral lip while a number of irregularly distributed papillae are observed in the present nematode. Also, it differs in the size of hook as it is smaller than that presented by Bursey and Goldberg, 2000. Also, the present species differs from $H$. minuta Andrews, 1974 that described from skink Leiolopisma smithi as the latter has 11 pairs of caudal papillae one pair is precloacal and the remainder are postcloacal and the presence of two pairs of papillae on each cephalic lip.

On the other hand, the present species is similar to large extent to $H$. spinigera described by Luque et al. (2010) from fish Retropinna retropinna and Aldrichetta forsteri from New Zealand in the presence of 10 pairs of subventral papillae but the distribution of these papillae are different in the two species. It is arranged as one pair precloacal, one pair adcloacal and the remainder are postcloacal papillae in case of $H$. spinigera. While it differs from the previous species in the larger spicules, the presence of two pairs of papillae on each lateral lip in H. spinigera and thw absence of cephalic papillae while two pairs of cephalic papillae and unknown number of labial papillae are recorded on the pseudolapia in the present specimen. Females have small- 
er tail hook in H. spinigera than in the present species.

In the present survey, the present species recorded from Lane Snapper Lutjanus synagris as new species because it is distinguished from other species of the genus by the presence of four pseudolapia, one small submedian and three larger posterior ones. The large spicules of male and the arrangement of caudal papillae in male one pair are precloacal and nine pairs are postcloacal.

A proposed key for identification the described species of genus Hedruris from fishes according to the number of caudal papillae:

1- Caudal papillae more than 10 in number..................H. longispicula Thomas, 1959

- Caudal papillae less than 10 in number arranged as one pair lateral and eight pairs subventral H. suttonae Brugni and Viozzi, 2010

- Caudal papillae 10 in number........................................... 2, 3,4

2- Caudal papillae 10 in number, one pair precloacal and remainder post-cloacal ..Hedruris lutjanses sp.n.

3- Caudal papillae 10 in number and all papillae post-cloacal. H. bryttosi Yamaguti, 1935

4- Caudal papillae 10 in number distributed as one pair precloacal papillae, one pair adcloacal and remainder postcloacal papillae.................................. spinigera ........................Luque; Vieira; Herrman; King; Poulin and Lagrue, 2010

Hosts: Lutjanus synagris Linnaeus, 1758

Locations: Stomach and intestine.

Localities: Egypt.

Type specimen: Number 1, Collection of present species sent to helminthological collection at British Museum.

SEM: Surface topography of nematode Hedruris lutjanses sp. $\mathrm{n}$. has been examined. It revealed the presence of four submedian pseudolabia at the cephalic end which considered as important taxonomic character for that genus. Only two large pseudolabia are described by Brugni and Viozzii (2010) for $H$. suttonae by SEM. Similar four pseudolabia are described by Moravec et al. (2007) for Comephoronema oschmarini (Nematoda, Cystidicolidae) from Lota lota. The pseudolabia with projected teeth are similar to those observed in Physaloptera clausa by Gorgani et al. (2013) from European hedgehog Erinaceus europaeus from Iran. The interlabia are weekly developed or absent in the present specimen on the contrast the interlabia are recorded by Brugni and Viozzii (2010) for $H$. suttonae.

A number of small and large irregularly distributed papillae on the outer surfaces of pseudolabia are observed in the present nematode of both males and females. The number of labial papillae may be variable in genus Hedruris. The papillae differ in shape and their distribution on pseudolabia from those of $H$. spinigera described by Clark (1978) and those of $H$. bryttosi and H. neobythitis studied by Yamaguti (1941) as thay are digitiformlike papillae distributed as anterior pair and posterior one in the last two species.

Two amphids are present in Hedruris lutjanses sp. n., such amphids like those described by Petter (1971) in H. androphora and noted in the original descriptions of $H$. minuta Andrews, 1974 and H. spinigera Baylis, 1931. The previous authors considered that the amphids are situated in the longitudinal midline of the pseudolabia at a level more anterior than that of the labial papillae. Haukeland (1993) reported that the presence of amphids in males for finding females in order to mate. SEM showed that the cuticular annulations of the body are dissimilar to previous reported species of Hedruris nematode of taxonomic character for different species differentiations. 
The total parasitic infection rate was (36.7\%), which was higher than that recorded from Galaxias maculates (5.9\%), from Perca fluviatilis (14.7\%), from Rhombosolea retiaria (26.1\%) more or less similar to Salmo trutta
(39.1\%) for $H$. suttonae (Brugni and Viozzi, 2010). The percentage was lower (46.9\%) than recorded from Retropinna retropinna by the same previous author.

Table 1: A Comparison between present H. lutjanses sp. n. and other species

\begin{tabular}{|c|c|c|c|c|}
\hline Character & $\begin{array}{c}\text { H. minuta } \\
\text { Andrews (1974) }\end{array}$ & $\begin{array}{l}\text { H. hanleyae Bursey } \\
\text { and Goldberg (2000) }\end{array}$ & $\begin{array}{c}\text { H. spinigera Luque et } \\
\text { al. }(2010)\end{array}$ & $\begin{array}{l}\text { Hedruris sp. } \mathrm{n} . \\
\text { present work }\end{array}$ \\
\hline $\begin{array}{l}\text { Body length male } \\
\text { female }\end{array}$ & $\begin{array}{l}2.55-3.20 \\
2.05-2.85\end{array}$ & $\begin{array}{c}5.92-7.88 \\
4.4-7.2\end{array}$ & $\begin{array}{c}7.5 \\
10.12\end{array}$ & $\begin{array}{c}1.9-2.5 \\
2.6-3\end{array}$ \\
\hline $\begin{array}{c}\text { Body width male } \\
\text { female }\end{array}$ & ----- & $\begin{array}{l}0.14-0.16 \\
0.12-0.18\end{array}$ & $\begin{array}{c}0.14 \\
0.4\end{array}$ & $\begin{array}{c}0.45-0.68 \\
0.42-0.6\end{array}$ \\
\hline $\begin{array}{c}\text { Head length male } \\
\text { female }\end{array}$ & $\begin{array}{l}50 \mu \mathrm{m} \\
65 \mu \mathrm{m}\end{array}$ & 0.10-0.15 & $\begin{array}{l}77 \mu \mathrm{m} \\
89 \mu \mathrm{m}\end{array}$ & $\begin{array}{l}40 \mu \mathrm{m} \\
56 \mu \mathrm{m}\end{array}$ \\
\hline $\begin{array}{l}\text { Oesophogus length } \\
\text { male } \\
\text { female }\end{array}$ & $\begin{array}{c}0.6-0.7 \\
0.66-0.83\end{array}$ & $\begin{array}{c}0.84-1.1 \\
0.84-1.15\end{array}$ & $\begin{array}{c}13.50 \\
19\end{array}$ & $\begin{array}{c}0.48-0.55 \\
0.55-0.6\end{array}$ \\
\hline $\begin{array}{l}\text { Excretory pore } \\
\text { from anterior } \\
\text { extremity male } \\
\quad \text { female }\end{array}$ & $\begin{array}{c}0.22-0.28 \\
----\end{array}$ & $\begin{array}{l}0.27-0.36 \\
0.29-0.40\end{array}$ & $\begin{array}{l}0.43 \\
0.49\end{array}$ & $\begin{array}{l}0.19-0.21 \\
0.22-0.23\end{array}$ \\
\hline $\begin{array}{l}\text { Tail long male } \\
\text { female }\end{array}$ & $\begin{array}{l}---- \\
----- \\
\end{array}$ & $0.36-0.43$ & 0.23 & $\begin{array}{l}0.3 \\
0.5 \\
\end{array}$ \\
\hline Vulva & $0.46-0.69$ & $0.77-1.08$ & 1.22 & $0.39-0.41$ \\
\hline $\begin{array}{l}\text { Anus from } \\
\text { posterior end }\end{array}$ & $0.16-0.22$ & $0.36-0.55$ & 0.39 & $0.14-0.15$ \\
\hline Hook length & 0.19 & $0.26-0.29$ & 0.11 & $0.06-0.08$ \\
\hline $\begin{array}{l}\text { Egg length } \\
\text { width }\end{array}$ & $\begin{array}{l}50 \mu \mathrm{m} \\
17 \mu \mathrm{m}\end{array}$ & $\begin{array}{l}46-51 \mu \mathrm{m} \\
23-26 \mu \mathrm{m}\end{array}$ & $\begin{array}{c}28.5 \mu \mathrm{m} \\
14 \mu \mathrm{m}\end{array}$ & $\begin{array}{ll}75-90 & \mu \mathrm{m} \\
30-33 & \mu \mathrm{m}\end{array}$ \\
\hline Spicules & $160-168$ & $190-230$ & 200 & $195-240$ \\
\hline caudal papillae & 11 & 10 & 10 & 10 \\
\hline $\begin{array}{l}\text { Arrangement of } \\
\text { caudal papillae }\end{array}$ & $\begin{array}{l}\text { A pair preclo- } \\
\text { acal } \& 10 \\
\text { postcloacal }\end{array}$ & $\begin{array}{c}2 \text { pairs precloacal \& } \\
8 \text { postcloacal }\end{array}$ & $\begin{array}{c}\text { Pair precloacal, pair } \\
\text { adcloacal } \& 8 \\
\text { postcloacal }\end{array}$ & $\begin{array}{c}\text { A pair } \\
\text { precloacal \&9 } \\
\text { postcloacal }\end{array}$ \\
\hline Hosts & Skink L. smithi & $\begin{array}{c}\text { Lizard } \\
\text { H. garnotii }\end{array}$ & $\begin{array}{c}\text { Fish } G \text {. maclates, } \\
\text { R.retropinna and } A \text {. } \\
\text { australis }\end{array}$ & $\begin{array}{c}\text { Fish } \\
\text { L. synagris }\end{array}$ \\
\hline Location & Stomach & Stomach & Intestine & $\begin{array}{c}\text { Stomach \& } \\
\text { intestine }\end{array}$ \\
\hline Localities & New Zealand & Oceania & New Zealand & Egypt \\
\hline
\end{tabular}

Table 2: Prevalence of Hedruris lutjanses sp. n. in fishes related to sexes, weights and seasons 2013

\begin{tabular}{|c|c|c|c|c|c|c|c|c|c|c|c|c|c|}
\hline \multirow[b]{2}{*}{ Host } & \multirow[b]{2}{*}{ Sex } & \multirow{2}{*}{$\begin{array}{l}\text { Infect } \\
\text { Non. }\end{array}$} & \multirow[b]{2}{*}{$\mathrm{N}$. } & \multirow{2}{*}{$\%$} & \multirow{2}{*}{$\begin{array}{c}\text { Weight } \\
\text { (gms) }\end{array}$} & \multicolumn{2}{|c|}{ Spring } & \multicolumn{2}{|c|}{ Summer } & \multicolumn{2}{|c|}{ Fall } & \multicolumn{2}{|c|}{ Winter } \\
\hline & & & & & & $\mathrm{N}$. & $\%$ & N. & $\%$ & N. & $\%$ & $\mathrm{~N}$. & $\%$ \\
\hline \multirow{4}{*}{$\begin{array}{l}\text { Lutjanus } \\
\text { synagris }\end{array}$} & \multirow{2}{*}{$\hat{0}$} & Infec. & 20 & 45.45 & $40-135$ & 2 & 66.6 & 3 & 25 & 6 & 46.2 & 9 & 60 \\
\hline & & Non. & 24 & & $35-162$ & 1 & & 9 & & 7 & & 6 & \\
\hline & \multirow{2}{*}{ q } & Infec. & 24 & 31.58 & $20-150$ & 5 & 26.3 & 9 & 45 & 4 & 16 & 6 & 46.2 \\
\hline & & Non. & 52 & & $55-130$ & 14 & & 11 & & 21 & & 7 & \\
\hline Total & & & 12 & 36.66 & $20-162$ & 22 & 31.8 & 32 & 37.5 & 38 & 26.3 & 28 & 53.6 \\
\hline
\end{tabular}


Fig. A: Prevalence of infection with Hedruris lutjanses sp. n. related to fish sex

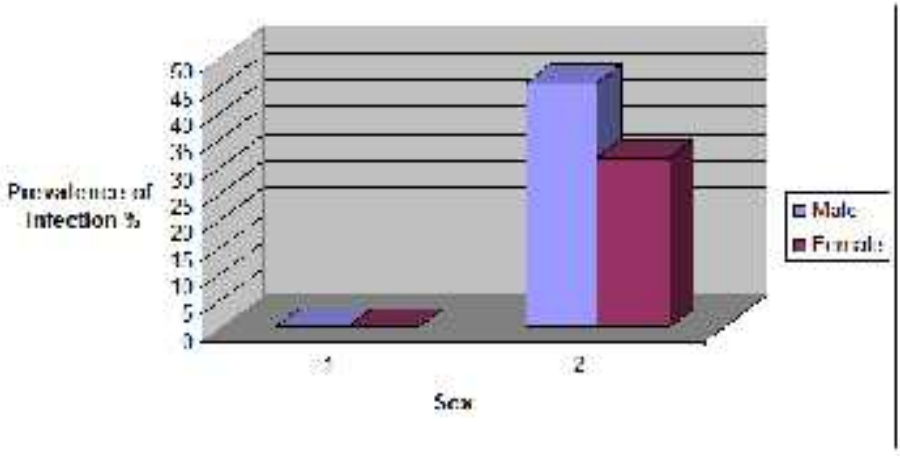

Fig. B: Prevalence of infection with $H$. lutjanses sp. n. in Lutjanus synagris seasonality

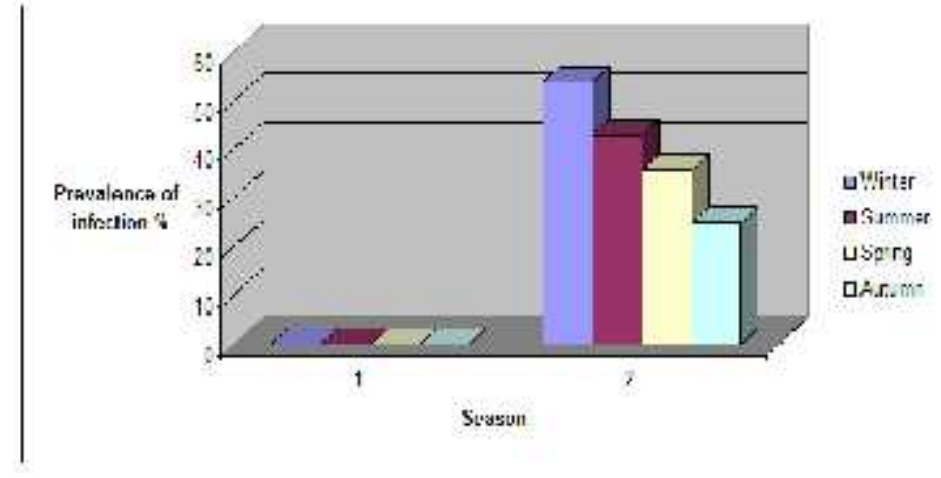

\section{References}

Abdou, Nel-S, Dronen, NO, 2007: Studies on the juveniles of a species of Anisakis (Nematoda: Anisakidae) from the orangespotted trevally, Carangoides bayad (Carangidae), from the Red Sea, Egypt. J. Egypt. Soc. Parasitol. 37, 3:1055-64.

Anderson, RC, 2000: Nematode parasites of vertebrates: Their development and transmission. $2^{\text {nd }}$ Ed. CABI Publishing. Wallinford, UK.

Andrews, HJR, 1974: A new species of Hedruris (Nematoda: Spirurida) from the skink Leiolopisma smithi. New Zealand J. Zool. 1, 3:329-32.

Baker, MR, 1986: Revisino of Hedruris Nitzsch (Nematoda: Habronematoidea) from aquatic vertebrates of North America. Can. J. Zool. 64:156772.

Brugni, NL, Viiozzi, GP, 2010: A new Hedrurid species (Nematoda) from galaxiid fishes in Patagonia (Argentina), and infection of amphipods as intermediate host. J. Parasitol. 96:109-15.

Burgees, EW, Axelord, RH, Hunziker, ER, 2002: Atlas of Marine Aquarium Fishes". Published by TFH Publications, $3^{\text {rd }}$ edition.
Bursey, CR, Goldberg, SR, 2000: Hedruris hanleyae n. sp. (Nematoda: Hedruridae) from Hemidacttylus garnotii (Sauria: Gekkonidae) from the Cook Inlands, Oceania. J. Parasitol. 86: 556-9. Bursey, CR, Goldberg, SR, 2007: New species of Hedruris (Nematoda: Hedruridae), Anuracanthorhynchus lutzi (Hamann, 1891) n. comb. And other helminthes in Lithobates warszewitshii (Anura: Ranidae) from Costa Rica. Carib. J. Sci. 43:1-10. Clark, WC, 1978: Head morphology and prehensile adaptations in Hedruris spinigera (Nematoda: Spirurida). N. Z. J. Zool. 5:497-501.

Dinar, A, 1995: Restoring and protecting the world's lakes and reservoirs. World Bank Publications. ISBN 0-8213-3321-6

Griffiths, WE, 1976: Hedruris spinigera (Nematoda: Spirurida) in stomachs of perch Perca fluviatilis L. N. Z. Mar. Freshwater Res. 10:533-6.

Gorgani, T, Naem, S, Farshid, AA, Otranto, D, 2013: Scanning Electron Microscopy observations of the hedgehog stomach worm, Physaloptera clausa (Spirurida: Physalopteridae)". Parasites and Vectors 6, 87:1-8. 
Hasegawa, H, 1989: Neoentomelas asatoi gen. and sp. n. (Nematoda: Rhabdiasidae) and Hedruris miyakoensis sp. n. (Nematoda: Hedruridae) from skins of the Ryukyu Archipelago, Japan. Proc. Helminthol. Soc. Wash. 56:145-50.

Hasegawa, H, Otsuru, M, 1979: Life history of an amphibian nematode, Hedruris ijimai Morishita, 1926 (Hedruridae). Jpn. J. Parasitol. 28:8997.

Jellyman, DJ, 1989: Occurrence of the nematode Hedruris spinigera in the stomachs of freshwater eels. N. Z. J. Zool. 16:185-9.

Luque, JL, Vieira, FM, Herrmann, K, King, TM, Poulin, R, Lagrue, C, 2010: New evidence on a cold case: trophic transmission, distribution and host specificity in Hedruris spinigera (Nematoda: Hedruridae). Folia Parasitol. 57, 3:223-31.

Moravec, F, 2007: Some aspects of the taxonomy and biology of adult spirurine nematodes parasitic in fishes: A review. Folia Parasitol. 54:239-57.

Morsy, K, Bashtar, A, Abdel-Ghaffar, F, Mehlhorn, H, Al Quraishy, S, et al, 2011: First record of anisakid juveniles (Nematoda) in the European seabass Dicentrarchus labrax (Family: Moronidae), and their role as bio-indicators of heavy metal pollution. Parasitol. Res.110:1131-8. Ortubay, SG, Semenas, LG, Ubeda, CA, Quaggiotto, AE, Viozzi, GP, 1994: "Catalogo de Peces Dulceacuícolas de la Patagonia Argentina y sus. Parásitos Metazoos. Dirección de Pesca, Río Negro, Argentina.

Petter, AJ, 1971: Redescription of d'Hedruris androphora Nitzsch 1821 (Nematoda: Hedruridae) et étude de son devéloppement chez I'hote intermédiaire. Ann. Parasitol. Hum. Comp. 46:479-95. Schultz, K, 2003: Field Guide to Saltwater Fish. Wiley, $1^{\text {st }}$ edition.

Yamaguti, S, 1963: The Nematodes of Vertebrates (Part I \& II), Systema Helminthum, Vol. III. Interscience Publisher Inc., New York and London.

Zahran, MA, 2008: The Vegetation of Egypt. Springer. ISBN 1-4020-8755-1 
A
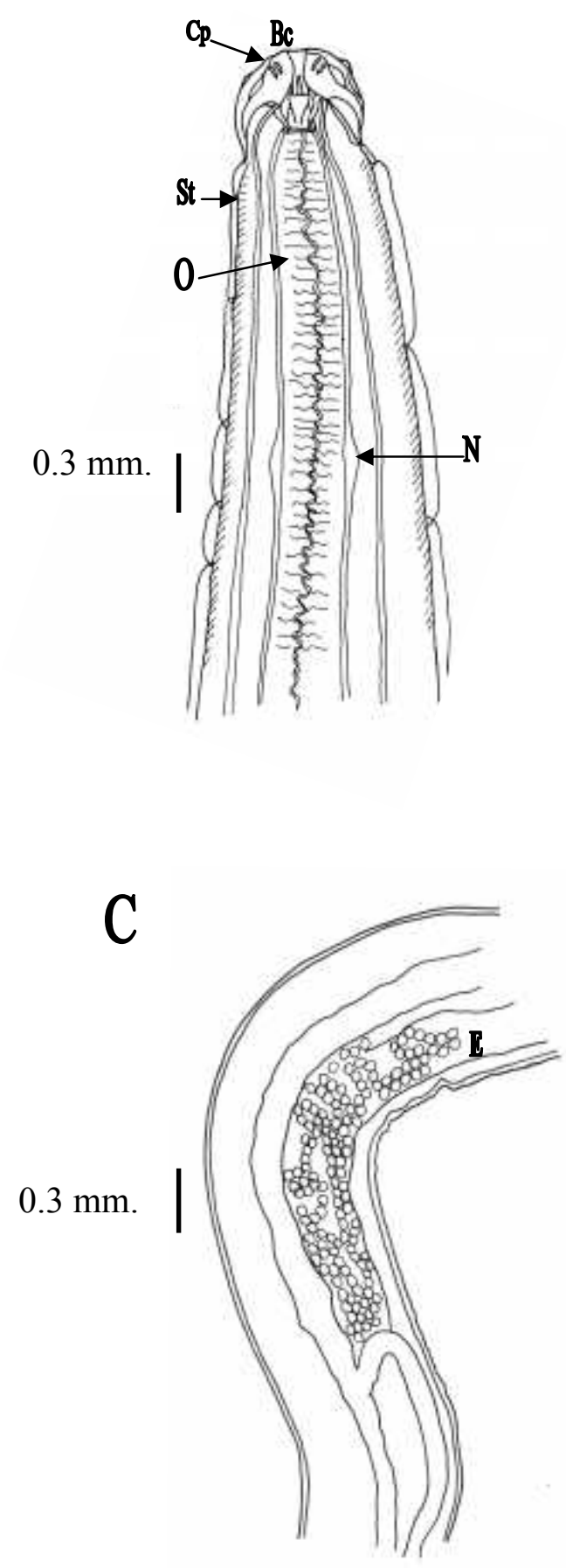

B
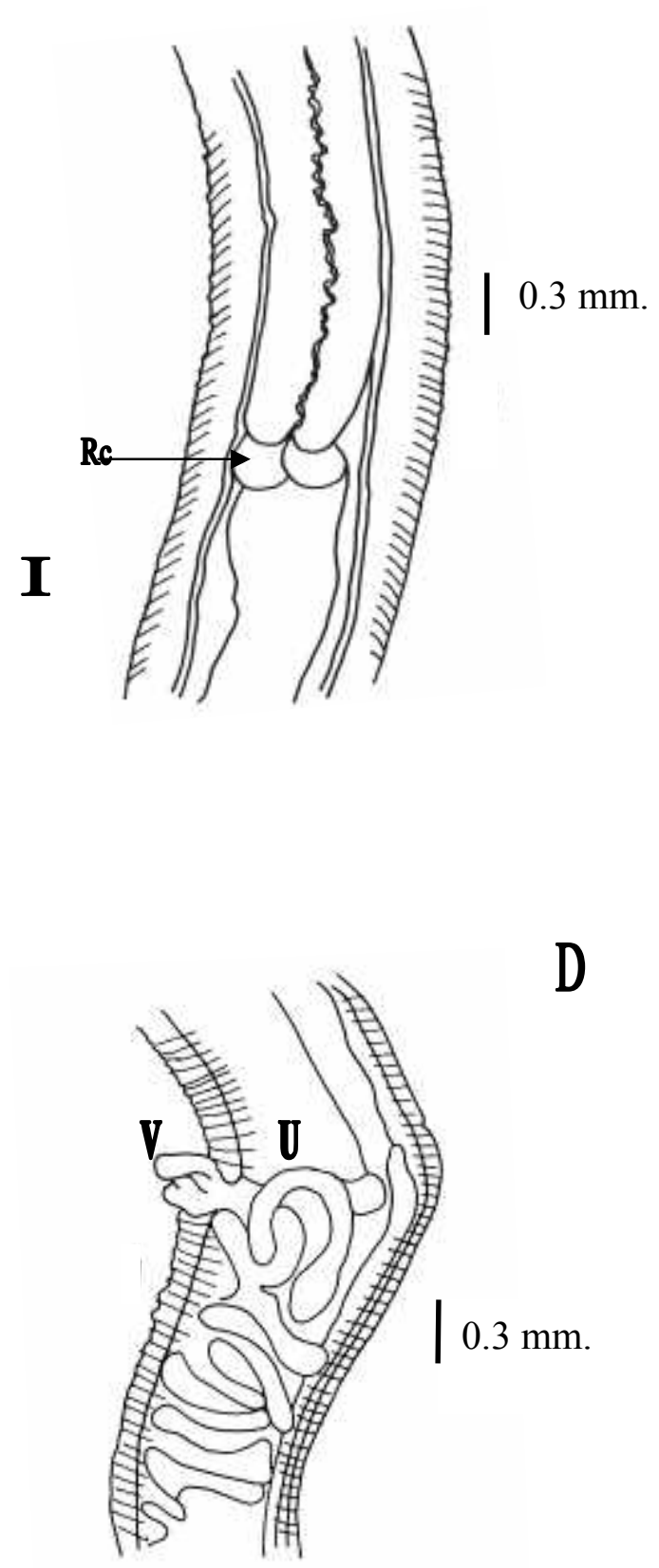

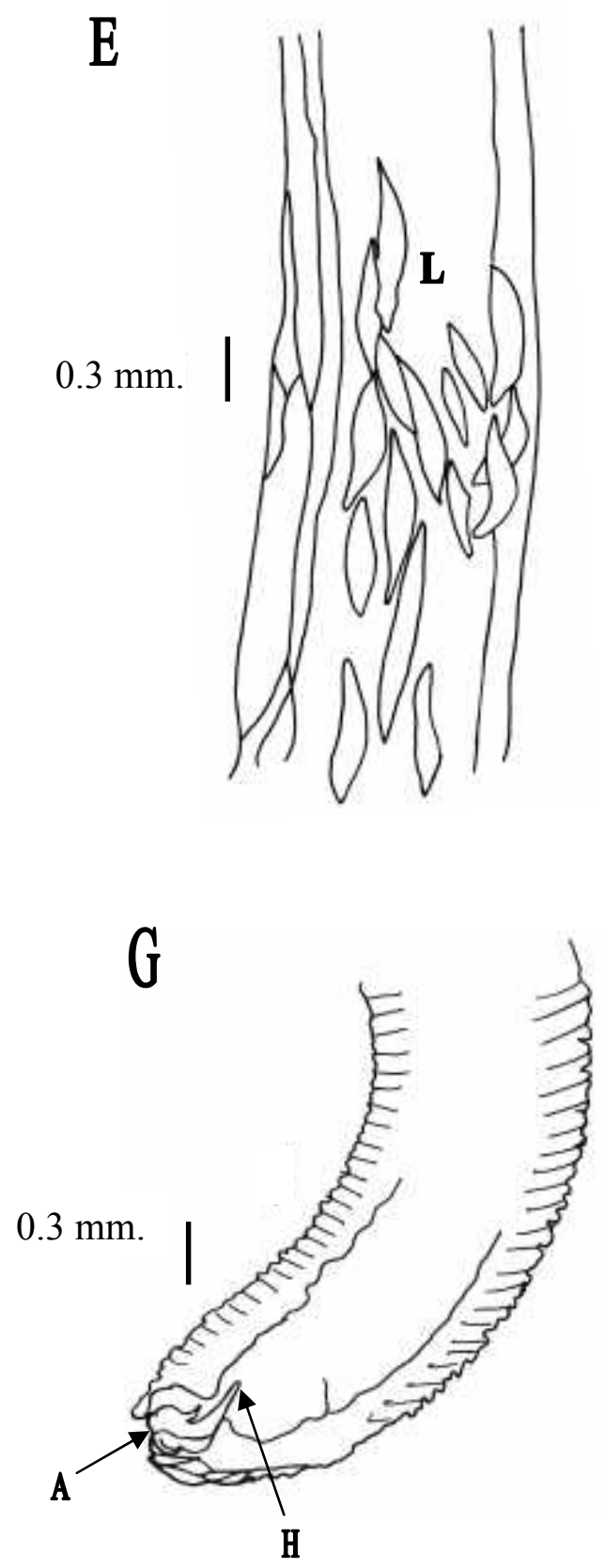

$\mathrm{F}$

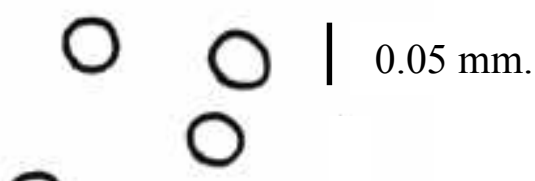

Camera Lucida of Hedruris lutjanses sp. n. Plate (1), Figures (A-H)

Fig. A: Worm anterior extremity showing buccal capsule (Bc), cephalic papillae (Cp), oeasophogial $(\mathrm{O})$, nerve ring $(\mathrm{N})$ and transverse striations $(\mathrm{St})$. Fig. B: Anterior part of worm showing ring cells $(\mathrm{Rc})$ and intestine (I). Fig. C: Median part of female worm showing eggs (E). Fig. D: Last third part of female showing uterus (U) and vulva (V). Fig. E: Female showing larvae (L). Fig. F: Eggs. Fig. G: Posterior extremity of female showing anus (A) and inverted hook (H), Fig. H: Posterior extremity of male showing spicules $(\mathrm{S})$, cloaca $(\mathrm{C})$ and caudal papillae $(\mathrm{Cp})$. 
Plate 2: Figs. A-I: SEM of Hedruris lutjanses sp. n.
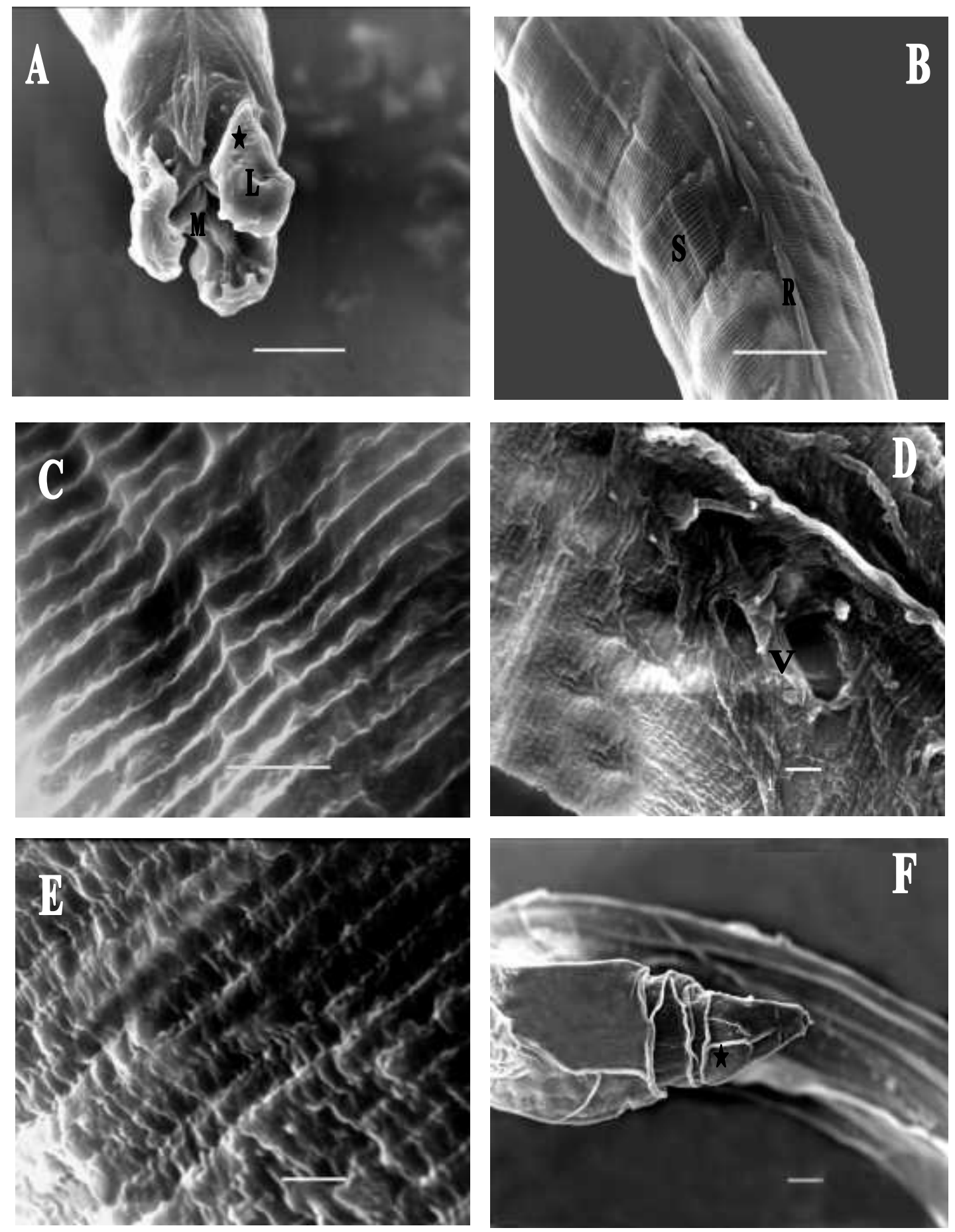

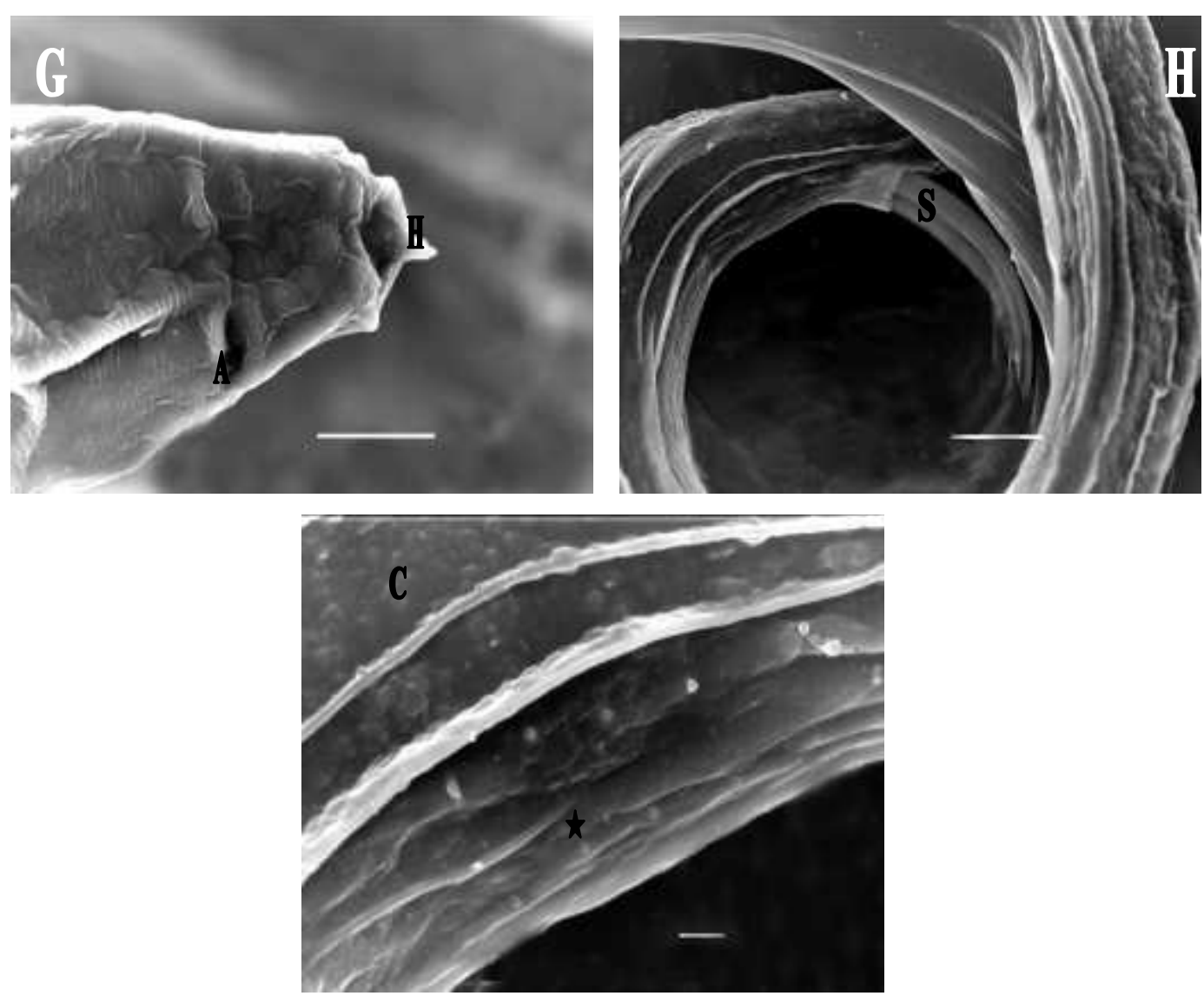

Fig. A: Anterior extremity, apical view showing three large pseudolabia L, papillae (star), buccal teeth (arrow) and mouth opening M. Bar $=50 \mu \mathrm{m}$.

Fig. B: Dorsal surface of nematode showing transverse striations $\mathrm{S}$ and longitudinal ridge $\mathrm{R}$. Bar=50 $\mu \mathrm{m}$.

Fig. C: High magnification of cuticular striations of first third of body worm. Bar $=5 \mu \mathrm{m}$.

Fig. D: Vulvar region of female worm on ventral surface showing vulva V. Bar $=10 \mu \mathrm{m}$.

Fig. E: High magnification of ventral surface of middle body showing cuticular ornamentation. Bar=5 $\mu \mathrm{m}$.

Fig. F: Tail region of female nematode showing cuticular ridges (star). Bar=100 $\mu \mathrm{m}$.

Fig. G: High magnification of posterior extremity of female showing anus A and hook-like structure H. $\mathrm{Bar}=50 \mu \mathrm{m}$.

Fig. H: Posterior extremity of male showing spicules S. Bar $=100 \mu \mathrm{m}$.

Fig. I: A high magnification of posterior cuticular body surface of male showing caudal papillae (star) and protruded cuticular structures C. Bar $=10 \mu \mathrm{m}$. 